\title{
ADDITIONAL NOTES ON THE GENUS LIPPIA. XI
}

Harold N. Moldenke

\section{LIPPIA Houst.}

Additional \& emended bibliography: J. C. \& M. Willis, Rev. Cat. Flow. Pl. Ceyl. [Parad. Man. Bot. 2:] 68 \& 159. 1911; A. \& I. Nehrling, Easy Gard. Drought-resist. Pl., imp. 1, 304. 1968; Rouleau, Guide Ind. Kew. IIl. 1970; A. \& I. Nehrling, Easy Gard. Drought-resist. PI., imp. 2, 304. 1975; Hocking, Excerpt. Bot. A. 28: 170, 257, \& 259. 1976; Lelong, Sida 7: 140. 1977; Moldenke, Biol. Abstr. 64: 6575. 1977; Powell, Econ. Bot. 31: 418, 419, \& 421. 1977; Moldenke, Phytologia 38: 230--266, 385--406, 474-482, $504-508,510, \& 512(1978)$ and 39: 24-46, 78--106, 162-182, 252-267, \& 391--395. 1978; A. L. Moldenke, Phytologia 39: 64. 1978 .

The Turner \& Crutchfield 6262, distributed as a Lippia sp., is Lantana macropoda f. albiflora Moldenke, while Graham \& Frohlich 1128 is Lantana velutina Mart. \& Gal.

An additional excluded taxon is Lippia scaberrima Altschul, Drugs \& Foods $244.1973=\underline{\text { Phyla }}$ scaberrima (A. L. Juss.) Moldenke.

\section{LIPPIA ABYSSINICA (Otto \& Dietr.) Cuf.}

Additional bibliography: Moldenke, Phytologia 38: 263--266 \& 385 (1978) and 39: 31, 32, 80, 81, 105, 181, \& 395. 1978.

LIPPIA ALBA (Mill.) N. E. Br.

Additional bibliography: Noldenke, Phytologia 38: 386--406 \& 474 (1978) and 39: 29, 86, 99, 104, 105, 167, 260, \& 264. 1978.

Material of this species has been misidentified and distributed in some herbaria as Aloysia chiapensis Moldenke. On the other hand, the Tharp, Follansbee, \& Thompson 51-1671, distributed as $\mathrm{L}$. alba, actually is Lantana macropoda Torr.

Additional citations: MEXICO: Chiapas: Ton 2186 (Ld).

LIPPIA ALBA var. GLOBIFLORA (L'Hér.) Moldenke

Additional bibliography: Moldenke, Phytologia 38: 474 (1978) and 39: 99, 104, 105, \& 260. 1978.

The Humboldt \& Bonpland photograph, cited below, is a transfer from the Britton Herbarium.

Fimended citations: VENEZUEJA: Apure: Humboldt \& Bonpland s.n. [Macbride photos 39485] (Z-photo).

LIPPIA AMIRRICANA L.

Additional bibliography: Moldenke, Phytologia 38: 474-477 \& 482 (1978) and 39: $93 \& 95.1978$. 
LIPPIA AMERICANA $f$. PILOSA Moldenke

Additional bibliography: Moldenke, Phytologia 38: 476-477. 1978.

Nee describes this plant as a shrub, $2 \mathrm{~m}$. tall, and found it growing in open weedy roadsides and open to brushy savanna pastures, at $100 \mathrm{~m}$. altitude, flowering in November. The corollas on Nee 8221 are said to have been "greenish-white" when fresh.

Material of this taxon has been misidentified and distributed in some herbaria as "Labiatae".

Additional citations: PANAMA: Veraguas: M. Nee 8221 (N).

\section{LIPPIA ARECHAVALETAE Moldenke}

Additional bibliography: Moldenke, Phytologia 38: 478--479 (1978) and 39: 28. 1978.

LIPPIA ASPERRTMA Cham.

Additional bibliography: Moldenke, Phytologia 38: 479-480 (1978) and 39: 180. 1978.

\section{LIPPIA BAHIENSIS Moldenke}

Additional bibliography: Hocking, Excerpt. Bot. A.28: 170 . 1976; Moldenke, Phytologia 38: 480. 1978.

LIPPIA BRACTEOSA (Mart. \& Gal.) Moldenke 1978 .

Additional bibliography: Mold enke, Phytologia 39: 24, 27, \& 87 .

Additional citations: MEXICO: Chiapas: Breedlove 23049 (Mi).

LIPPIA CALITCARPAFFOLTA H.B.K.

Additional bibliography: Moldenke, Phytologia 39: 25--27, 95, 252 , \& 256. 1978.

\section{LIPPIA CARDIOSTEGIA Benth.}

Additional bibliography: Moldenke, Phytologia 39: 28-30, 32 , $36,168,252,253,258, \& 266.1978$.

Recent collectors have encountered this species along roadsides in "dry mountain forest zone, most natural vegetation cleared for milpas", flowering in July. (N) .

Additional citations: GUATEMALA: Guatemala: Harmon \& Dwyer 3076

LIPPIA CHIAPASENSIS Loes.

Additional bibliography: Moldenke, Phytologia 39: 30, 32-34, \& 36.1978.

Recent collectors have found this species growing on slopes with montane rainforest of Liquidambar, Magnolia, and Vochysia, flowering in February and November. The corollas are said to have been "yellow" on Breedlove 33433.

Additional citations: MEXICO: Chiapas: Breedlove 33433 (Mi); Breedlove \& Dressler 29502 (Mi); Breedlove \& Thorne 21323 (Mi). 
LIPPIA CONTROVERSA Moldenke

Additional bibliography: Moldenke, Phytologia 39: 30, 32-34, 166 , \& 168. 1978.

Recent collectors have encountered this plant on "steep slopes with tropical deciduous forest along ravines". The corollas are said to have been "pale-yellow" on Breedlove 28294.

Additional citations: MFXICO: Chiapas: Breedlove 20375 (Mi), 28294 (Mi).

LIPPIA CORYMBOSA Cham.

Additional bibliography: Moldenke, Phytologia 39: $34--35$ \& 44 . 1978.

Irwin and his associates encountered this plant on brown sandy soil in cerrado and describe it as growing "from a thick root"; the corolla-tube on their no. 27508 is said to have been "white".

Additional citations: BRAZIL: Minas Gerais: Irwin, Fonsêca, Souza, Reis dos Santos, \& Ramos 27508 (Ld).

LIPPIA COSTARICENSIS Moldenke

Additional bibliography: Moldenke, Phytologia 39: 30, 35--36, 252 , \& 253. 1978.

Recent collectors refer to this species as a tree, $7 \mathrm{~m}$. tall, and have encountered it in fencerows, at $1300 \mathrm{~m}$. altitude, flowering in July.

Additional citations: PANAMA: Chiriqu1: Mori \& Bolten $\underline{7398}$ (N).

\section{LIPPIA ELEGANS Cham.}

Additional bibliography: Moldenke, Phytologia 39: 38-39, 263, \& 264.1978.

Additional citations: BRAZIL: Minas Gerais: Irwin, Fonsêca, Souza, Reis dos Santos, \& Ramos 27193 (Ac).

LIPPIA ELLIPTICA Schau.

Additional bibliography: Hocking, Excerpt. Bot. A.28: 170 . 1976; Moldenke, Phytologia 39: 24 \& 39. 1978.

LIPPIA ELLIPTICA var. SILVICOLA Moldenke

Additional bibliography: Hocking, Excerpt. Bot. A.28: 170. 1976; Moldenke, Phytologia 39: 39. 1978.

LIPPIA GRAVEOLENS H.B.K.

Additional \& emended bibliography: Coult., Contrib. U. S. Nat. Herb. 2: 328. 1892; Moldenke, Phytologia 39: 82-88, 91, 92, 256, $262,264, \& 267.1978$.

Recent collectors have found this species in shrubby secondgrowth on slopes and on slopes with Pimus, Quercus, and Acacia.

Additional citations: MEXICO: Chiapas: Breedlove 27656 (Mi), 28468 (Mi).

Additional bibliography: Hocking, Excerpt. Bot. A.28: 170. 
1976; Moldenke, Phytologia 39: 89. 1978.

LIPPIA HEDERAEFOLIA Mart. \& Schau.

Additional bibliography: Moldenke, Phytologia 39: 90. 1978.

Irwin \& al. 28442 originally consisted of a mixture of Lippia hederaefolia and the type collection of L. rosella Moldenke, the latter portion now cited as no. 28442 a.

Additional citations: BRAZIL: Minas Gerais: Irwin, Fonsêca,

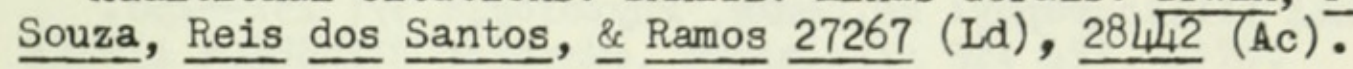

LIPPIA HIRSUTA var. MORITZII (Turcz.) Lopez-Palacios 1978 .

Additional bibliography: Moldenke, Phytologia 39: 92-95.

The Steyermark 104919, distributed as L. hirsuta var. moritzii, actually is L. schlimii Turcz.

LIPPIA JAVANICA (Burm. f.) Spreng.

Additional bibliography: Moldenke, Phytologia 39: 99-106, 393, \& 395. 1978.

Additional citations: SOUTH AFRICA: Cape Province: Collector undetermined s.n. [Mo. Bot. Gard. photos A.865] (W--photo).

\section{LIPPIA LINDMANII Briq.}

Synonymy: Lippia lindmannii Briq. ex Moldenke, Phytologia 39: 166, sphalm. 1978 .

Additional bibliography: Hocking, Excerpt. Bot. A.28: 170. 1976; Moldenke, Phytologia 39: 166. 1978.

LIPPIA LINDMANII $f$. OPPOSITIFOLIA Moldenke

Synonynt Lippia lindmannii f. oppositifolia kíldenke, Phytologia 39: 166, sphalm. 1978 .

Additional bibliography: Hocking, Excerpt. Bot. A.28: 170 . 1976; Moldenke, Phytologia 39: 166. 1978.

LIPPIA LUPULINA Cham.

Additional bibliography: Moldenke, Phytologia 39: 168--172 \& 266. 1978 .

Additional citations: BRAZIL: Distrito Federal: Irwin, Fonsêca, Souza, Reis dos Santos, \& Ramos 26361 (Ld).

LIPPIA MICROCEPHALA Cham.

Additional bibliography: Moldenke, Phytologia 39: 174--175. 1978 .

Additional citations: BRAZIL: Minas Gerais: Irwin, Fonsêca, Souza, Reis dos Santos, \& Ramos 28309 (Ac).

LIPPIA MICROMERA Schau.

Additional bibliography: Hocking, Excerpt. Bot. A.28: 170 . 1976; Moldenke, Phytologia 39: 175-178. 1978. 
LIPPIA MYRIOCEPHAIA Schlecht. \& Cham. 1978 .

Additional bibliography: Moldenke, Phytologia 39: 252--258.

Recent collectors have encountered this plant on "slopes with small streams, tropical rainforest along the ridges".

Additional citations: MEXICO: Chiapas: Breedlove 26515 (Mi).

LIPPIA MYRIOCEPHALA var. HYPOLEIA (Briq.) Moldenke 1978 .

Additional bibliography: Moldenke, Phytologia 39: 252-258.

Recent collectors have found this plant growing on "steep slopes with montane rainforest" (Mi).

Additional citations: MEXICO: Chiapas: Breedlove \& Thorne 20947

\section{LIPPIA POHLIANA Schau.}

Additional bibliography: Moldenke, Phytologia 39: 395. 1978.

Recent collectors have encountered this plant in "grassy campo with scattered trees, on crystal sand, wet in some places" and in "quartzite rock outcrops and sandy soil with cerrado", at altitudes of 1000--1370 m., flowering in January, April, and May, fruiting in Jamary. Irwin and his associates refer to it as "occasional".

The corollas are said to have been "white" on Anderson 8063, "dark-rose" on Hatschbach \& al. 29099, "red-violet, the throat white" on Irwin 즈. 222254, and "tube yellow, lobes white" on Anderson 9995 .

The Lippia nepetacea Schau., previously regarded by me as con-

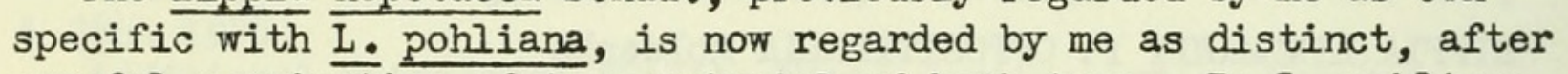
careful examination of type material of both taxa. In L. pohliana the bracts are wide-spreading and long-acuminate, while in L. nepetacea they are closely appressed and merely acute.

Additional citations: BRAZIL: Goiás: W. R. Anderson 8063 (Ac, N), 9995 (Ld, N); J. E. Pohl s.n. [in Brasilia] (Ku--l15--cotype, Mu116-cotype, $\mathrm{z}$-cotype). Minas Gerais: Hatschbach, Smith, \& Ayensu 29099 (Ld, W-2744564); Irwin, Reis dos Santos, Souza, \& Fonsểca $\underline{22254}(\mathrm{~N}, \mathrm{Z}), \underline{22466}(\mathrm{Ac}, \mathrm{N})$.

LIPPIA POHLIANA var. LONGIBRACTEOLATA Moldenke, Phytologia 31: 385. 1975.

Bibliography: Moldenke, Phytologia 31: 385. 1975; Hocking, Excerpt. Bot. A.28: 170. 1976; Moldenke, Phytologia 39: 78. 1978.

Anderson and his associates describe this plant as a shrub, 0.4 m. tall, the corollas pink with a yellow eye, and found it growing in cerrado in an area of rocky sandstone cerrado and open rocky hillsides with white sandy soil sloping down to grassy brejo (sedge meadow), creek, and gallery forest, at $1220 \mathrm{~m}$. altitude, flowering in February.

Naterial of this variety has been misidentified and distributed in some herbaria as L. gracilis Schau. 
Citations: BRAZIL: Linas Gerais: Anderson, Stieber, \& Kirkbride 35371 (Ld--isotype, N-type, W-2709310-isotype).

LIPPIA POLYTRICHA Briq.

Additional bibliography: Burkart, Excerpt. Bot. A.5: 586. 1962; Noldenke, Phytologia 12: 355-356. 1965; Noldenke, Fisth Summ. 1: 186 (1971) and 2: 893. 1971; Troncoso, Darwiniane 18: 340 \& 410. 1974 .

LIPPIA POSSENSIS Moldenke, Phytologia 32: 457. 1975.

Bibliography: Moldenke, Phytolog1a $32: 457$ (1975) and 34: 258. 1976; Anon., B1ol. Abstr. 61: ACl.640. 1976; Hocking, Bxcerpt. Bot. A.28: 259. 1976.

C1tations: BRAZIL: Golás: Gottsberger \& Gottsberger 138-2577 (z-type).

LIPPIA PRAECOX Mildbr.

Additional bibliography: Moldenke, Phytolog1a 12: 356-357. 1965; Moldenke, Fifth Summ. 1: 250 (1971) and 2: 893. 1971.

LIPPIA PRETOFIENSIS H. H. W. Pearson

Additional \& emended bibliography: H. H. W. Pearson in Thiselt.Dyer, Fl. Cap. 5: 193 \& 197. 1901; Watt \& Breyer-Brandrijk, Med. \& Poison. PI. S. Afr., ed. 2, 1052 \& 1410. 1962; Moldenke, Phytologia 13: 365. 1966; C. A. Sm., Common Names S. Lfr. P1. 320, 321, 323, \& 601. 1966; Moldenke, Fifth Summ. 1: 257 (1971) and 2: 542, 553, \& 893. 1971; Hegnauer, Chemotax. Pfl. 6 [Chem. Reihe 21]: 674.1973.

Smith (1966) reports the vernacular names, "laventelbos", "laventelbossie", "lekkerruickbossie", and "leventelbossien", and asserts that sheep eating this plant become jaundiced and photosensitive. Fatt \& Brejer-Brandwijk (1962) report "photosensitization accompanied by icterus...... is less toxdc than Lippia rehmanni", citing their nos. 1049, 1050, 1052, \& 1067.

Pearson (1901) separates this species from the other South African species know to him as follows:

1. Calyx distinctly 2-lobed.

2. Bracts more than 2 lines long and 1 1/2 lines broad, exceed-

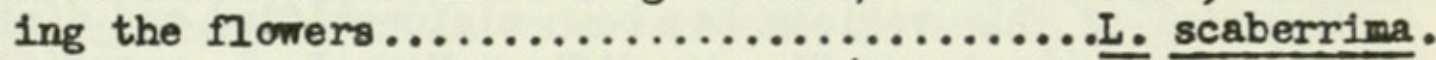

2a. Bracts less than 2 lines long and $1 / 2$ line wide, not ex-

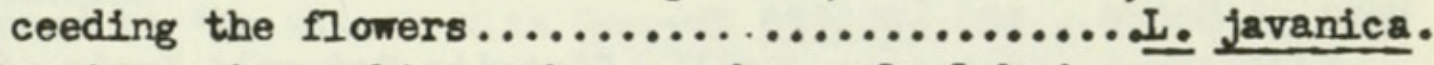

1a. Caljx truncate, subtruncate, or obseurely lobed.

3. Leaves serrate or crenate-serrate.

4. Bracts more than 2 lines long; caljx truncate or obscurely

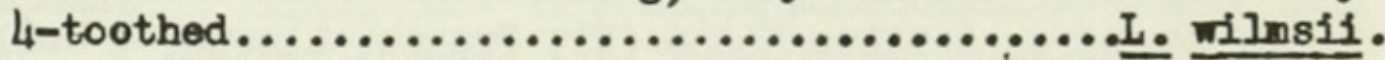

4a. Bracts 1 ess than 2 lines long; calyx obscurely $\overline{2-l o b e d .}$

5. Adult leaves elliptic, not more than 1 inch

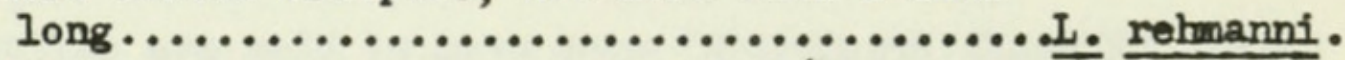

5a. Adult leaves ovate, more than $11 / 2$ inches

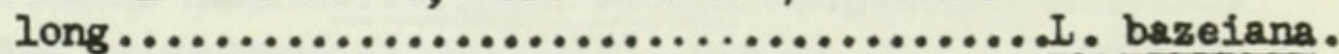

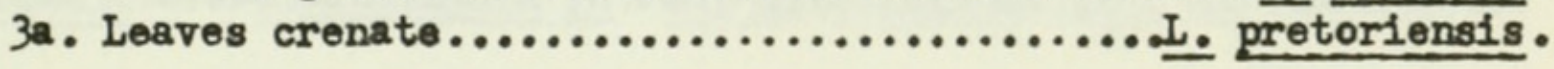


The Meebold 12829, distributed as I. pretoriensis, actually is L. Wlimsil H. H. W. Pearson.

Additional citations: SOUTH AFRICA: Transvaal: Burke $402(\mathrm{Pd})$.

LIPPIA PRTMULINA S. Moore

Additional bibliography: Moldenke, Phytologia 13: 365. 1966; Angely, Fl. Anal. \& Fitogeogr. S. Paulo, ed. 1, 4: 835 \& xi. 1971; Moldenke, Fifth Summ. 1: 156 (197) and 2: 893. 1971; Troncoso, Darwiniana 18: 339 \& 410. 1974; Molcenke, Phytologia 34: 258 (1976) and 39: W4 \& 80. 1978.

Irwin and his associates describe this plant as a simple shrub or subshrub, 0.75-1 m. tall, the bracts red- or rose-violet, and found it growing on wet campo slopes, at $950 \mathrm{~m}$. altitude, flowering in June and October. They refer to it as "infrequent". The corollas are said to have been "magenta" on Irwin \& al. 17812 and "rose-violet" on Irwin \& Soderstrom 7115 .

The Angely (1971) work cited above bears an incorrect "1970" titlepage date.

Material of L. primulina has been misidentified and distributed in some herbaria as I. gardnerians Schau.

Additional c1tations: BRAZIL: Goiás: Irwin \& Soderstrom 7115 (Ac, N); Irwin, Souza, Grear, \& Reis dos Santos $17812(\mathrm{~N}, \mathrm{Z})$.

LIPPIA PRTMULINA var. GOYAZENSIS S. Moore

Additional bibliography: Moldenke, Phytologia 12: 360. 1965; Moldenke, Fifth Sunm. 1: 156 (1971) and 2: 893. 1971; Moldenke, Phytologia 39: 80. 1978 .

Recent collectors describe this plant as an herb to $30 \mathrm{~cm}$. tall, from a woody root, and have found it in burned-over cerrada flowering just after the burning from August to October, at altitudes of $700-1200$ meters.

The corollas are said to have boen "rose" on Fonsêca 294, "rose-lavender" on Maguire \& al. 56346, "rose-violet, the throat wite" on Irwin \& al. 8577, "rose-lavender, throat yellow with a white border" on Irwin \& 29. 8739, and "purple with yellow eye in center surrounded by 2 wite area, some purple without eye" on Prance \& al. 18949.

Material of this variety has been misidentified and distributed in some herbaria as "L. grandiflora Mart.", L. grandiflora Mart. \& Schau., and Lantana sp.

Additional citations: BRAZII: Distrito Federal: Irwin, Souza, \& Reis dos Santos 8577 (Ac, N), 8739 (Ld, N). Goiḱs: S. da Fons8ca 294 (Z); Lïtzelburg 1465a (Mu). Mato Grosso: Maguire, Murça Pires, Maguire, \& Silve 56346 (N); Prance, Lleres, \& Coêlho 18949 $(\mathrm{Ld}, \mathrm{N})$.

\section{LIPPIA PRINGLEI Br1q.}

Additional synonyus: Lippia longifolia Pavon ex Moldenke, Fifth Summ. 18 559, in syn. 197 [not I. longifolia Sesse \& Moc., 
1940].

Additional bibliography: Cummins, Lloydia 3: 16 \& 62. 1940; Hock1ng, Excerpt. Bot. 1.7: 454. 1964; Moldenke, Phytologia I4: 414. 1967; Uphor, Dict. Econ. P1., od. 2, 315. 1968; Gibson, Fieldiana Bot. 24 (9): 213 \& 216. 1970; Moldenke, Fifth Summ. 1: 72 \& 366 (1971) and 2: 550-552, 557, 559, \& 893. 1971; Farnsworth, Pharmacog. T1tles 7 (10): ix. 1972; Fong, Trojánkova, Trojánek, \& Farnsworth, Lloydia 35: 147. 1972; Moldenke, Phytologia 23: Lili. 1972; Altschul, Drugs \& Foods 24h. 1973; [Farnsworth], Pharmacog. Titles 7, Cum. Gen. Ind. [72]. 1975; Hinton Rzedowsk1, Anal. Esc. Nac. Clenc. Biol. 21: 75. 1975; Moldenke, Photologia 39: 25, 27, 253, \& 256. 1978 .

Recent collectors describe this plant as a large shrub or amall tree, 3-10 m. tall, the trunk 8-15 cm. in diameter at breast height, the "branches whorled" and weak, the follage "heavy", the leaves odorous, the bracts greentsh-white or pale greenish-yellow, the "inflorescence pale-green" or "heads pale", and the flowers aromatic, visited by tymenoptera, and have found it growing in wet or medium-met soil in olk woods, in open sun, on the sides of arroyos, in ravines and narrow valleys, in secondary matorral, in woods of Ipomoea and legumes, and near water in shady canjon bottoms, at altitudes of 20-2400 meters, Nowering from November to February and in April and September, fruiting in February and Norember. Delgadillo says "fruto caf'". The leaf-blades on the 2uccarini Herbarium material cited below are $26-33 \mathrm{~cm}$. Iong and $9--10.5 \mathrm{~cm}$. Wide, the petioles $2.5-4.5 \mathrm{~cm}$. long!

Kruse reports the species "frequent on slopes with woods of Quercus elliptica and Lysilona acapulcensis in association with Acacia pennatula, 'crece en suelos de arcilla pedregosa con pH6's Rzedow ski \& McVaugh found it on "calizas karsticas con regetacion de matorral secundario" and "fondo de la barranca". The

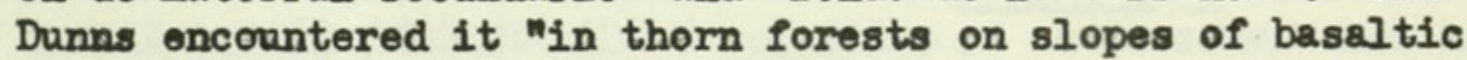
block knolls" and the Andersons found it to be "common shrubs or trees in regenerating pine forests with other trees mixed and adventive". MeVaugh speaks of it as "abundant on shaded outcrops of dogtooth limestone in oak forests with some P1mus lumholtzei on steep rockg slopes", "abundant in tall humld forests with Fraxims, Quercus, Abies, Almus, and Clusian", and "in steep valley in decajing granitic solls with oak-pine forest on ridges and F1cus, Couepia, and other broad-leaves troes in the valley". Breedlove found It "on slopes with quercus and Erythring along small streams", on "steep moist north-facing slopes with Carpims, Cor mus, Clethra, PImus, and Quercus", and "on steep east-facing slopes with Pimus lumholtail, P. herrerai, Quercus epileuce, Q. viminea, and Arbutus xalapensis". McVaugh reports it "locally abundant", Dieterle "fairly common", and Nlava \& Cook "common in shrubbery" .

The corollas are said to have been "white" on Breedlove 18678 and Ortega 6548, "yellow" on Anderson \& Anderson 5605 \& 5606 , Breodlore \& Kawahare 16943 \& 17073 , Dieterle 4211, Ernst 2146, 
Kruse 55, MacDougell H.284, Palacios s.n., and Rzedowski 21881, "jellowish" on Rzedowski 25255, "creamish-yellow" on Alava \& Cook 1616, "yellowish-white" on Ortega 5707, "greenish-yellow" on Mc Vaugh 25993, "greenish" on Mc7augh 26108, "greenish-white to Jellow" on McVaugh 25494, "pale-orange" on Hinton 13482, and "rose" on Delgadillo 209 .

Vernacular names reported for Lippia pringlei include "bacarton", "choila", "chokili", and "matayaki". Altschul (1973) reports the occurrence of a medicinal sap in this plant useful in treating toothache (by chewing of the bark?) and that the leaves are also put into hot water, then coated with nentholatum, and applied to bruises and sores, in the treatment of headaches, etc.

It should be noted here that the L. longifolia of Pavon appears to be based on Pavon 36, labeled, doubtless in error, as from "Perun, deposited in the Paris herbarium. The L. longifolia of Sessé \& Moçino is a synonym of Phyla stoechadifolis (L.) Small. Uphof (1968) reduces L. pringlei to the synonyur of L. umbellata Cav. Gibson (1970) thinks that L. jurgensenil Briq., regarded by me as a synouym of I. pringle1, may, instead, actually be the oldest name for the plant now known as L. salamensis Loes.

Cunmins (1940) reports the parasitic fungi, Prospodium conjunctum (D. \& H.) Cumins and P. Iippiae (Speg.) Arth., from Iippia pringlei in Mexico, based on Holway s.n. [Oaxaca, Oct. 23, 1899, type] and Holway 5399 for the former and Holway s.n. [Iguala, Guerrero, Oct. 4, 1900] and s.n. [Oaraca, Oct. 23, 1899, type of Uredo lippiae D. \& H.].

Loesner (1912) citos Seler 1460 \& 1743 from Oaxaca, Mexico.

Material of $\mathrm{L}$. pringlei has been misidentified and distributed in some herbaria as L. callicarpaefolia H.B.K., L. hypoleia Briq., L. umbellata Cav., "L. umbellata Cav. sensu lato", and Buddleia sp. On the other hand, the Wiggins 13187, distributed as L. pringlei, actually is I. gentryi Standl.

Additional c1 tations: MEXICO: Guerrero: Hinton 11278 (Ld); Kruse 55 (Ip); J. Rzedowski 25255 (Ip, Ki); Rzedowski \& McVaugh 307 (Ip, Id). Jalisco: Breedlove 17678 (Id); R. McVaugh 25494 (Mi), 25993 (Mi), 26108 (Mi); Pringle 1733 (Ms-30881-isotype, Mu-1812-isotype, Mu-1813-isotype), 2743 (In-70014); J. Rzedowski 21881 (Ip, Ki, Ws); Villarreal de Puga 68 (Ip), 166 (Ip). Michoacán: Hinton 12949 (Se-97685, Tu $=112082), 13482 \overline{(\mathrm{Se}-}$ 110740, Tu-92068, Tu-112024), 13614 (Se-97683, Tu-112039). Morelos: Bourgeau 1217 (Ki); Dunn \& Dunn 18631 (N); R. Palacios s.n. $[14 / \overline{I X / 1964]} \overline{(I p)}$, s.n. $\overline{[2 / X I / 1964]} \overline{(I p), ~ s . n . ~[14 . ~ X I . ~} 1964]$ $\overline{(I p)}$, s.n. (Mi); Pringle 13982 (BI-149656, Tu-134745). Nayarit: Alava \& Cook 1616 (Ca-1322452); Gentry, Barclay, \& Arguelles $19 \overline{637}$ (Id); R. P2lacios s.n. [17/XI/1968] (Ni); Tempieton 
7003a (N). Oaxaca: Anderson \& Anderson 5605 (Sd-78919), 5606 (Mi); L. Conzatt1 4826 (Ld); Delgadillo 209 (T-2790790), 220 (W-2790793); Dieterle 4211 (Mi); Ernst 2446 (Mi, W--2798515), 2476 (Mi, W-2798516), $2558(\mathrm{~W}-2798514) ; \mathrm{T}$. MacDougall H.284 (N); R. McVaugh 22282 (Ip); Makrinius 568 (T-1842816); J. Rzedowskd 19280 (Au-243566, Ip); Seler \& Seler 1460 [Macbride photos 17497] (w-1205956, w-photo), 1743 (w-1205962). Sinaloa: Breedlove \& Kawahara 16943 (Ac), 17073 (Ld); Cummins 70-220H (Tu178283); J. G. Ortega 5707 (Mu), 6548 (Mu); C. L. Smith 193 (Tu183232). Sonora: Gentry 4814 (Tu-98608). State undetermined: Gregg 930 (E-116644, E-116646), 937 (E-116645); Karwinski s.n. [Hab. In Mexico] (Mu-139); Pavon 36 ["Peru", 1868] (P); K. Reiche 1029 [Esperanza] (Ku). CULTIVATED: Germany: Herb. Zuccarint s.n. [h. Monac. 1835] (Mu-142), s.n. [Hortus Monac. anno 1845] (Mu141), s.n. [Hortus bot. Monacensis] (Mu--143); Kummer s.n. [Hort. Monac. 1849.3.I] (Mu--140. MOUNTED DESCRIPTIONS: Loes in Fedde, Repert. Spec. Nov. 9: 366. 1911 (T).

LIPPIA PRIMGLET $f$. INTECTA Moldenke

Additional bibliography: Moldenke, Phytologia 12: 365. 1965; Moldenke, Fifth Surm. 1: 72 (1971) and 2: 893. 1971; Moldenke, Phytologia 23: 4ل14. 1972.

McVaugh refers to this plant as a tree, $5 \mathrm{~m}$. tall, with flowers that are "orange-yellow on opening, fading to pale-cream", and found it to be "locally abundant in sunny spots in steep rocky valloy in tall subdeciduous forest of hura, Brosimum, Bursera, Psidium, and Hymenaea", at $150 \mathrm{~m}$. altitude, flowering in December. Additional citations: MEXICO: Jalisco: R. MeVaugh 25543 (Mi).

LIPPIA PSEUDO-THEA (A.St.-Hil.) Schau.

Additional synonym: Lantana pseudothea L. ex Friese, Bol. Agricult. Sao Paulo 34: 317. 1933.

Additional \& enended bibliography: J. Grah., PI. Bomb. 156. 1839; Spach, Hist. Nat. Veg. Phan. 9: 243. 1840; Lindl., Veg. Kingd. 663. 1846; Schau. in A. DC., Prodr. 11: 582 \& 608. 1847; Twining, Ill. Nat. Ord. P1. 2: 104. 1855; Buek, Gen. Spec. Syn. Candoll. 3: 253 \& 266. 1858; Schnitzl., Iconogr. Fam. Nat. 2: 137 Verbenaceae [2]. 1856; Archer, Profit. PIs. 126. 1865; T. Peckolt, Bericht. Deutsch. Pharm. Gesell. 14: 470. 1904; Friese, Bol. Agrioult. Sa Paulo 34: 317. 1933; Darlington \& Janald Ammal, Chrom. Atl. 27. 1945; Grieve, Modern Herb. 486. 1967; Moldenke, Phytologia 14: 414. 1967; Uphor, Dict. Bcon. P1., ed. 2, 315. 1968; Moldenke, Fifth Sunm. 1: 157 (1971) and 2: 542, 563, \& 893. 1971; Hedrick, Sturterant's Edible Pl. 338. 1972; Moldenke, Phytologia 31: 402 (1975) and 39: 42. 1978.

Recent collectors describe this plant as a small shrub, 1-2 m. tall, and have encountered it on campos and rocky campos, as well as in sandy soil near rivers, at $1200-1300 \mathrm{~m}$. altitude, flowering in June and September. Hatschbach says that he found 
it in "solo arenoso junto com afloramentos de areniton. The corollas are sald to have been "yellow" on Willians \& Assis 7160 , "rose" on Hatschbach 27252 \& 27491 , and "purple" on Hatschbach 30140. Hatschbach reports the plant as being "Untuoso ao tacta".

The Schnitzlein (1856) reference, cited above, is often cited as having been pablished in "1843-1870", the titiepage dates, but the pages relating to the Verbenaceae were actually issued in 1856.

Spach (1840) says "Cette espèce croit au Brfsil, dans la province des Minas. Ses feuilles ont une odeur très-aromatique; s6chbes et prises en infusion, elle donnent une boisson trèsagréable et fort estimbe dans le pays". Uphof (1968) reports its leaves used as a tea in some parts of Brazil; Grieve (1967) also reports its use as a "substitute for tea and its fruit is eaten". Twining (1855) adds that it is employed in Chile in aromatic baths.

Friese (1933) says "Lantana pseudothea L. ........parcialmente conhecidas sob o nome de cambará ou camark (vejamse este verbete) encontram emprego medicamentoso das suas folhas que, provarelmente por causa des pequenas quantidades de oleo essencial que encerram, infuso mostram effeitos sudorificos e antipyreticos".

Pockolt (1904) tells us concerning Lippia pseudo-theas "Auf den Steppengebieton des Staates Minas mit mehreren Volksnamen: Cha de frade - Mrnchstoe, Capitar do mato - Negerfyngertee und als hrufigste Benenmunge Chá de pedestre - Tee des Fussreisendenl He describes the plant as a "Strauchartige Pflanze mit lanxettlichen, spitzen, an der Basis abgerundeten, ganzrandigen, oberseits papill8s-borstigen, unterseits rauhhaarigen Blyttern. Bliten klein und weiss. Die Blatter sind ungemein wohlriechend, den Steppenbewohner ein tKgliches, wohlschmeckendes Getrank; es ersetzt inm Kaffee, Tee usw. Auch als Heilmittel sehr geschatrt bei allen katarrhalischen Affektionen sowie als Stimulans und Diuretikum. Die Pflanze verdiente kultiviert zu werden, sie witude Itr die Parfumerle ein wertvolles atherisches ol ilefern".

Naterial of this species has been misidentified and distributed in some herbaria as I. Florida Cham.

Additional citations: BRAZIL: Minas Gerais: Glaziou 19709 (Mu-4328); Hatschbach 27250 (W-2706627), 27252 (Ld), $\frac{27491}{(\mathrm{~N})}$ (Ld), 30140 (N, W-2706992, Z); Williams \& ssis $1160(\mathrm{G}, \mathrm{N})$.

\section{LIPPIA PUNIIA Cham.}

Additional synonyus: Lippia pumila Cham. \& Schl. ex Moldenke, Phytologia 36: 4h, in syn. 1977.

Additional bibliography: Buek, Gen. Spec. Syn. Candoll. 3: 266. 1858; Angely, FI. Anal. Paran., ed. 1, 576. 1965; Hocking, Excerpt. Bot. A.10: 27 (1966) and A.1l: 103. 1967; Moldenke, Phytologia 14: 414. 1967, Moldenke, Fifth Sum. 1: 157 (1971) and 2: 892. 1971; Moldenke, Phytologia 36: 44 (1977) and 39: 259. 1978.

The Irwin, Souza, \& Reis dos Santos 9085 , distributed as I. pumila, actually is I. nana Schau., while Martius s.n. [Serra de 
S. Ant.] is Lantana glaziovil Moldenke.

LIPPIA RADULA J. G. Baker

Additional \& emended bibliography: J. G. Baker in Thiselt.Dyer, F1. Trop. Afr. 5: 278 \& 279. 1900; Moldenke, Phytologia 12: 430-431. 1965; Moldenke, Fifth Summ. 1: 241 (1971) and 2: 542, 564, \& 893. 1971; Moldenke, Phytolog1a 39: 181 \& 394. 1978.

The Kassas, Khalifa, \& Mobarak 128, distributed as L. radula, actually is $\mathrm{L}$. multiflora Moldenke.

\section{LIPPIA RAYBOI Moldenke}

Additional bibliography: Moldenke, Phytologia 13: 366. 1966; Moldenke, Biol. Abstr. 50: 12950. 1969; Hocking, Excerpt. Bot. A.15: 422. 1970; Reitz, Sellowia 22: 81. 1970; Moldenke, Fifth Summ. 1: 157 (1971) and 2: 893. 1971.

Additional citations: BRAZIL: Rio Grande do Sul: Rambo 52156 (B), $\underline{54583}$ (B).

LIPPIA RAMBOI var. PILOSA Moldenke, Phytologia 18: 294. 1969.

Bibliography: Moldenke, Phytologia 18: 294. 1969; Hocking, Excerpt. Bot. A.15: 422. 1970; Moldenke, Fifth Suma. 1: 157 (1971) and 2: 893. 1971 .

C1tations: BRAzIL: Rio Grande do Sul: Palacios \& Cuezzo 1516 (N-type).

\section{LIPPIA RBCOLLETAE Morong}

Additional synonymy: Lippia recolletae Mold. ex Moldenke, Phytologia 26: 374 , in syn. 1973.

Additional \& emended bibliography: Briq. in Chod. \& Hassler, Bull. Herb. Boiss., ser. 2, 4: 1156-1157. 1904; Briq. in Chod. \& Hassler, P1. Hassler. 2: 492-493. 1904; Michalowski, Serv. Tecn. Interam. Coop. Agr. Bol. 169. 1954; Teague, Anal. Mus. Hist. Nat. Montev., ser. 2, 7 (4): 45. 1965; Moldenke, Biol. Abstr. 47: 6792 . 1966; Hocking, Excerpt. Bot. A.11: 450. 1967; Moldenke, Phytologia 14: 474. 1967; Moldenke, Fifth Summ. 1: 183, 186, \& 199 (1971) and 2: 564 \& 893. 1971; Moldenke, Phytologia 26: 374.1973.

Recent collectors describe this plant as a semiprostrate herb, shrub, or subshrub, 0.3-l m. tall, erect, and aromatic, and found it growing in sandy loam, on campos, among grass on dry hills, and at the edge of gallery forests, at altitudes of 216-3350 m., flowering in Jamary, February, May, and October, and in fruit in Jamuary and October. They record the vernacular names, "falsa salvia" and "salvia blanca". The corollas are said to have been "whitish" on Hatschbach 23847, "white" on Quarin \& al. 1567, "yellow" on King \& Bishop 7577, "yellowish" on Lourteig 2012, "white and orange" on Fiebrig 4452 , and "rojiso purpurino pálido" on Steinbach 740. King \& Bishop refer to the plant as "abundant spreading coarse herb".

Teague (1965) reports that the plant is "common" and ruderal in Paraguay, sometimes spreading to cotton or manioca flelds, and cites Teague 267 . 
Additional citations: BRAZIL: Mato Grosso: Hatschbach 23847 (N), 39200 (Id). BOLIVIA: Cochabamba: King \& Bishop 7577 (W$2813112) ;$ R. F. Steinbach 740 (N, Ws). PARAGUAY: Fiebrig 4452 $(\mathrm{Mu}-4125)$, 5139 (Mu-4132); Lourteig 2012 (N); Montes 10996 (Mu); Quarin, Ishikawa, \& Schinini 1567 (Ld); Schinini 9171 (Ld); Woolston $173(\mathrm{~N}), 1637(\mathrm{~N})$. ARGENTINA: Corrientes: Burkart 19390 (N); Krapovickas \& Cristobal 11816 (W-2481392), 15792 (Ld, Ws). Misiones: Bertoni 2 [Herb. Inst. M. Lillo 99229] (Ut-3305458); T. Meyar $11378(\mathrm{~N})$; Montes $430 \mathrm{~b}(\mathrm{~N}), 15091$ (Ba), 27655 (Au271297, L $\overline{d, N}$ w-2556006).

LIPPIA RECOLLETAF var. PICKFIII (Moldenke) Moldenke

Additional bibliography: Moldenke, Biol. Abstr. 47: 6792. 1966; Hocking, Excerpt. Bot. A.11: 450. 1967; Moldenke, Phytologia 14: 414. 1967; Moldenke, Fifth Summ. 1: 186 (1971) and 2: 563 \& 894 . 1971.

\section{LIPPIA REHMANNI H. H. W. Pearson}

Emended synonymy: Lippia rehmannil H. H. W. Pearson ex Moldenke, Resumé 316, in syn. 1959; Dyer, Verdoorn, Codd, \& Letty, Wild Fls. Transv. 281. 1962.

Additional \& emended bibliography: Rimington \& al., Onderstepoort Journ. Vet. Sci. 9: 225-255. 1937; Roets, Onderstepoort Journ. Vet. Sc1. 9: 583-588. 1937; Anon., U. S. Dept. Agr. Bot. Subj. Index 15: 14358. 1958; Karrer, Konstit. \& Vork. Organ. Pflanzenst. 20 \& 819. 1958; Anderson, De Kock, \& Enslin, Journ. S. Afr. Chem. Inst. 14: 58. 1961; Dyer, Verdoorn, Codd, \& Letty, Wild Fls. Transv. 281 \& [282], pl. 140, fig. 4. 1962; Watt \& Breyer-Erandwijk, Med. \& Poison. Pl. S. \& East. Afr., ed. 2, 479, 1049, 1050, 1052-1053, 1067, \& 1410. 1962; H. K. Urban, Pharmazie 21: 336--339. 1966; Moldenke, Phytologia 14: 414. 1967; H. K. Urban, Bioresearch 1967: 1467. 1967; J. M. M. Br., Journ. S. Afr. Vet. Med. Assoc. 39 (3): 35-48. 1968; Anon., Biol. Abstr. 50 (1): S.107 (1969) and 50 (6): S.114. 1969; J. M. M. Br., Biol. Abstr. 50: 2969. 1969; Moldenke, Fifth Summ. 1: 230, 255, \& 257 (1971) and 2: 536, 542, 551, 564, \& 894. 1971; Boar \& Alien, Phytochem. 12: 2575. 1973; Farnsworth, Pharmacog. Titles 8 (12): vii. 1973; Hegnauer, Chemotsx. PfI. 6 [Chem. Reihe 21]: 673-675. 1973; Moldenke, Phytologia 34: 261 (1976) and 39: 105. 1978.

Emended illustrations: Dyer, Verdoorn, Codd, \& Letty, Wild Fls. Transv. [282], pl. 140, fig. 4' [in color]. 1962.

Recent collectors describe this plant as a rather spreading subshrub with a woody base and thick softish roots, the leaves pleasantly and strongly aromatic, and the flowers odorous, and have found it growing at altitudes of $1300-1400$ meters. The corollas are said to have been "white" on Werderman \& Oberdieck 1289 and "white to cream" on Winter 7518.

Smith (1966) records the vernacular names, "laventelbossien, "lekkerruickbossie", and "leventelbossie". 
A notation on the label indicates that root material of winter 7518 was collected for chemical analysis. Karrer (1958) reports that rehmannic acid or lantaden $\mathbf{A}, \mathrm{C}_{35} \mathrm{H}_{52} \mathrm{O}_{5}$, occurs in Lippia rehmanni as well as in Lantans camara and notes the presence of icterogenin A \& C, $\mathrm{C}_{35} \mathrm{H}_{52} \mathrm{O}_{6}$, only in Lippia rehmanni. Anderson and his associates (1961) report the presence of hederagenin (22 $\beta$ angeloyloxy) and treleasegenic acid.

Watt \& Breyer-Brandwijk (1962) assert that a condition almost indistinguishable from tribulosis and geeldikkop in sheep is caused by ingestion of the follage of Lippla rehmanni (as well as those of Tribulus spp. and Panicum spp.), apparently due to the presence in the leaves of icterogenin A, B, \& $C$ and rehmannic acid mostly in the root bark but also in the leaves. They also report that in Vietnam the plant is used as a diuretic.

Brown (1968) describes the hematology and chemical pathology of icterogen from Lippia rehmanni intoxication in sheep, indicating typical intrahepatic cholestasis and severe photosensitivity. The main effects of icterogenin are on the membrane permeability, especially the liver cell membranes, with the membranes of the kidneys, muscle cells, and erythrocytes affected to a lesser degree. Urban (1966) states that the plant's extract can be used to induce triperpenoid icterogenin dermatological reversible jaundice in the treatment of psorlasis and bed sores in rats.

Some Pretoria botanists reduce L. rehmanni to the synonymy of L. Wilmsil H. H. W. Pearson, but Pearson (1901) separates the three closely related taxa as follows:

Leaves crenate................................ pretoriensis. Leaves serrate.

Bracts $4 \mathrm{~mm}$. or more in length...................... wilmsii.

Bracts less than $4 \mathrm{~mm}$. long................... L. rehmanni. It should also be noted here that Codd 6554, originally distributed as L. rehmanni, is regarded by me as representing L. javanica (Burm. f.) Spreng. although it appears to match perfectly the photograph of the type specimen of $L$. rehmanni preserved in the New York Botanical Garden herbarium. Meeuse may be correct in his belief that the two tera are conspecific.

Material of $L$. rehmanni has been misidentified and distributed in some herbaria as L. asperifolia Rich., L. Wilmsil H. H. W. Pearson, Corchorus kirkij N. E. Br., and even Peucedanum caffrum Phillips. On the other hand, the Schweickerdt 1222, distributed as L. rehmannit, definitely is L. javanica (Burm. f.) Spreng. and Scheepers $\underline{192}$ is L. scaberrima sond.

Additional \& emended citations: NAMIBIA: Baum 250 (F-photo, $\mathrm{K}, \mathrm{N}, \mathrm{N}$--photo, $\mathrm{Sg}$-photo, Z-photo). SOUTH AFRICA: Transvaal: Meebold 12830 (Mu); Werdermann \& Oberdieck 1289 (W-2586066); Winter 7518 ( Mu $)$. 


\section{IIPPIA RETICULATA Hayek}

Additional bibliography: Moldenke, Phytologia 12: 436-437. 1965; Moldenke, Fifth Summ. 1: 157 (1971) and 2: 894. 1971.

IIPPIA RHODOCNEIS Mart. \& Schau.

Additional gynonym: Lippia rhodocnemis Mart. ex Moldenke, Photologia 36: 4h, in syn. 1977 .

Additional bibliography: Buek, Gen. Spec. Syn. Candoll. 3: 266. 1858; Farl., Proc . Am. Acad. Sci. 18: 83. 1883; Speg., Anal. Soc. Ci. Argent. 17: 93. 1884; Sydow, Monog. Ured. 1: 309. 1902; Sydow, Ann. Yyc. 5: 338. 1907; Speg., Anal. Mus. Nac. Buenos Aires 19: 313. 1909; H. S. Jacks •, Kycologia $24: 64$. 1932; Moldenke, Phytologia 12: 437-438. 1965; A. L. Moldenke, Phytologia 18: 121 \& 123. 1969; Moldenke, Fifth Summ. 1: 157 (1971) and 2: 564 \& 894. 1971; Troncoso, Darwinians 18: 339 \& 410. 1974.

Recent collectors have described this plant as a shrub, $2 \mathrm{~m}$. tall, and have encountered it on outcrops in areas of campo on white sand and cerrado among outcrops, at 1200 m. altitude, flowering in March.

Jackson (1932) records the fungus, Puccinia lantanae Farl. (1883) from this host on the basis of Holway 1006 from Rio de Janeiro, Brazil, listing as synonyms P. accedens Sydow (1902), P. privae Sydow (1907), Uromyces lantanae Speg. (1884), and U. Iippiae Speg. (1909).

The Tavares 630, distributed as L. rhodocnemis, actually is Lantana radula Sw.

Additional citations: BRAZIL: Minas Gerais: Irwin, Fonsêca, Soura, Reis dos Santos, \& Ramos 28507 (Id); Martius 1474 (Mu123-type, $\mathrm{z}$-isotype) . MOUNTEN ILLUSTRATIONS: Schau . in Mart., Fl. Bras. 9: pl. 40. $1851(\mathrm{~N}, \mathrm{Z})$.

LIPPIA RIBDMLIAM Schau.

Additional bibliography: Buek, Gen. Spec. Syn. Candoll. 3: 266. 1858; Moldenke, Phytologia 12: 439. 1965; Angely, F1. Anal. \& Fitogeogr. Est. S. Paulo, ed. 1, 4: 835 \& xi. 1971; Moldenke, Fifth Summ. 1: 152 (1971) and 2: 894. 1971.

\section{IIPPIA RIGIDA Schau.}

Additional bibliography: Buek, Gen. Spec. Syn. Candoll. 3: 266. 1858; Moldenke, Phytologia 12: 439-440. 1965; Moldenke, Fifth Summ. 1: 157 (1971) and 2: 894. 1971.

Recent collectors describe this plant as a spindly erect shrub, 2-3 m. tall, with brittle erect or steeply ascending stems and branches, the leaves dark- or mid-green above, paler or gray-green beneath, strongly rugose, and the bracts palogreen. They have found it growing in burned-over grassland and in low woodland on sand with laterite, along a "small stream with marsh on white sand and surrounding cerrado on sandstone rock exposures", and "in damp open sandy areas and small streams with poorly developed gallery forest", at 950-1200 m. altitude, flow- 
ering and frulting in January and March. The corollas are said to have been "Cream-color" on Harley \& al. 16708 .

Additional citations: BRAZIL: Bahia: Harley, Renvoize, Erskine, Brighton, \& P1nheiro in Harley 15602 (Z), 15756 (Ld), 16708 (Ac); Martius s.n. [in sylvis Catingas prope Maracas, Nov.; Macbride photo 20332] (ku-124--type, Z--isotype).

LIPPIA RODRIGUEZII Moldenke

Additional bibllography: Moldenke, Phytologia 12: $440-441$. 1965; Moldenke, Fifth Summ. 1: 199 (1971) and 2: 564 \& 894. 1971; Troncoso, Darwiniana 18: 340 \& 410. 1974.

This species has been encountered by recent collectors nentre el pasto", in anthesis in March, April, and September to Jamuary, in fruit in January. The corollas are said to have been "orangen on Schwarz 5114 and "yellow" on Schinini \& al. 8344. .

Through a typographic error, the surname "Schwarz" appears as "Schulz" in Phytologia 12: 4lil" (1965).

Additional citations: ARGENTINA: Corrientes: Schinini, Arbo, González, Ishikawa, \& Tressens 834山 (Id). Misiones: J. E. Yontes 14764 (Au--271306, N, Z); G. J. Schwarz 1533 (Ms-34188), 4924 $(\mathrm{N}), 5030(\mathrm{~N}), 5114(\mathrm{~N}), 5398(\mathrm{~N}), 5634(\mathrm{~N}), 5782(\mathrm{~N})$.

LIPPIA RONDONEMSIS Moldenke, Phytologia 20: 79. 1970.

Bibliography: Moldenke, Phytologia 20: 79. 1970; Anon., Biol. Abstr. 52 (3): B.A.S.I.C.S.134. 1971; Moldenke, Biol. Abstr. 52: 1316. 1971; Moldenke, Excerpt. Bot. A.18: 445. 1971; Moldenke, Fifth Summ. 1: 157 \& 183 (1971) and 2: 894. 1971; Heslop-Harrison, Ind. Kew. Suppl. 15: 80. 1974; Moldenke, Phytologia 38: 398. 1978.

Recent collectors describe this plant as an herb or straggling shrub, 0.5-1 m. tall, and found it in flower in June and July. The corollas are said to have been "pale-violet" on Prance \& al. 5847 and "lilac-pink, with yellow throat" on Prance \& 2l. 5351 .

Material of this species has been misidentified and distributed in some herbaria as L. alba (Mill.) N. E. Br., to which it is obviously closely related, and as Labiatae sp.

Citations: BRAZIL: Rondonia: Prance, Philcox, Forero, Coŝlho, Ramos, \& Farias 5351 (Ac, N); Prance, Forero, Wrigley, Ramos, \&

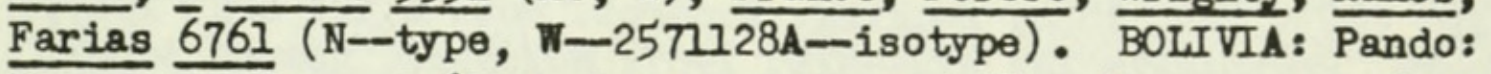
Prance, Forero, Coêlho, Ramos, \& Farias 5847 (Mu, N, W--2571127A).

LIPPIA ROSETIA Moldenke, sp. nov.

Suffrutex fragilis basaliter xylopodifformis; caule solitario gracile usque ad $20 \mathrm{~cm}$. alto tetragono dense puberulo stricto densissime folioso; folits parvis arcte imbricato-adpressis ellipticis ca. $1 \mathrm{~cm}$. longis $5 \mathrm{~mm}$. latis apicaliter obtusomsubacutis basaliter truncato-subcordatulis marginaliter regulariter serrulatis revolutis utrinque dense puberulis supra impresso-subbullatis; inflorescentils solitarils apicaliter axillaribus; pedunculo gracile $1.8-2 \mathrm{~cm}$. longo canescenti-puberulo; capitulis solitarifs subglobosis multifloris ca. $1.5 \mathrm{~cm}$. latis; bracteis involucriform- 
ibus ovatis perconspiculs arcte imbricatis ca. $7 \mathrm{~mm}$. longis $4 \mathrm{~mm}$. latis apicaliter acutis vel brevissime acuminatis extus pubervils ciliatis.

A brittle subshrub rising from a woody xylopodium; stems usually solitary per season, very slender, about $20 \mathrm{~cm}$. tall, tetragonal, strict and unbranched, densely puberulent throughout, densely leafy (except toward the base); internodes mostly quite regular and abbreviated, $1 \mathrm{~cm}$. long or less; nodes slightly enlarged; leaves very mumerous, closely antrorsely appressed and imbricate, very uniform, elliptic, small, about $1 \mathrm{~cm}$. Iong and $5 \mathrm{~mm}$. wide, apically obtuse or subacute, basally truncate or slightly subcordate, marginally regularly serrulate and revolute, densely puberulent on both surfaces, sessile; inflorescence solitary (per season), axillary toward the tip of the season's growth, ascendingerect; peduncles filiform, $1.8-2 \mathrm{~cm}$. long, canescent-puberulent; head solitary, hop-like, small, subglobose, many-flowered, about $1.5 \mathrm{~cm}$. long and wide; bracts forming a distinct basal involucre, large and conspicuous, apparently reddish or purplish when fresh, ovate, closely imbricate in many series, about $7 \mathrm{~mm}$. long and $5 \mathrm{~mm}$. wide, apically acute or very shortly cuspidate, marginally ciliate, externally puberulent; corolla hypocrateriform, rose-pink, its tube equaling the subtending bract, the limb $2-2.5 \mathrm{~mm}$. wide.

The type of this curious little species was collected by $H_{\text {. }} \mathrm{S}$. Irwin, S. F. de Fonsêca, R. Souza, R. Reis dos Santos, and J. Ramos (no. 28442a) - as a mixture with their no. 28442, I. hederaefolia Mart. \& Schau. - - in cerrado in an area of cerrado and campo ca. $3 \mathrm{~km}$. north of Sto Jolo da Chapada, on the road to Inhaf, at 1200 m. altitude, in the Serro do Espinhaco, on the Planalto do Brasil, Minas Gerais, Brazil, on March 29, 1970, and is deposited in my personal herbarium.

Citations: BRAZIL: Minas Gerais: Irwin, Fonsêca, Souza, Reis dos Santos, \& Ramos 28442a (Z--type).

LIPPIA ROSUNRINIFOLIA Anderss ., Ver. Akad. Handl. Stockh. 1853: 198. 1854 .

Synonjmy: Iippia rosmarinifolia var. rosmarinifolia Moldenke in Wiggins \& Porter, FI. Galáp. Isls. 491 \& 493, fig. 129c. 1971.

Additional \& emended bibliography: Anderss., Vet. Akad. Handl. Stockh. 1853: 198. 1854; Hocking, Excerpt. Bot. A.12: 424. 1967; Moldenke, Phytologia 14: 414--415. 1967; Moldenke, Résumé Suppl. 15: 4. 1967; Colinvawx, Schofield, \& Wiggins, Science 162: 114h. 1968; Moldenke, Biol. Ábstr. 49: 1325. 1968; Moldenke in Wiggins \& Porter, FI. Galáp. Isls. 491-494, fig. 129c. 1971; Wiggins \& Porter, F1. Galáp. Isls. 253 \& 989. 1971; Eliasson, Bot. Notiser 125: 53, 55, \& 57. 1972; Balgooy, Pacif. P1. Areas 3: 244. 1975; Van der Werfe, Bot. Notiser 130: 96.1977.

Iliustrations: Moldenke in Wiggins \& Porter, Fl. Galáp. 49l, fig. 129c. 1971 .

Howell refers to this plant as shrubby, 3- 5 feet tall, the branches loosely spreading, the stems arching and growing toward the ground, and, when lodged in suitable crevices, rooting to form new 
plants - if the stem does not root directly it creeps along the surface of the rock in prostrate condition. Wiggins \& Porter describe it as a slender shrub, 2--3 m. tall, with more or less arcuate branches, while Wiggins \& Duncan call it a slender tree, 8 $\mathrm{m}$. tall, the trunk $1 \mathrm{dm}$. In diameter $1 \mathrm{~m}$. from the ground.

The corollas are said to have been "pale creamy-yellow or flesh-color" on Howell 9448 and "white" on Wiggins \& Porter 255. Collectors have found it growing on cinder ridges, at $125-470 \mathrm{~m}$. altitude, flowering in January and May.

Fosberg describes the plant as a "shrub l-2 m. tall (others seen tree-like, to $4 \mathrm{m.}$ )", the flowers pinkish to yellowish-pink, and found it growing on the southwest slope of Narborough island, where it was "common in [a] broad green strip running from [the] sumit to [the] sea, on well vegetated as lava with pumice in the cavities", at $300 \mathrm{~m}$. altitude, flowering in February. Eliasson found it at $400-450 \mathrm{~m}$. altitude namong patches of old lava weathered into gravel with sparse vegetation, with Alternanthera filifolia, Froolichia mudicaulis ssp. lanigera, Jasminocererus thouarsii var. sclerocarpus, etc., and on caldera with such other dominant trees and shrubs as Bursera graveolens, Croton scouleri, Scalesia microcephala, and Macraea laricifolia; 2lso on tufa cones". Wiggins \& Porter (1971) report that it is sometimes host to Phoradendron henslovil (Hook. f.) Robinson.

Van der Werff (1977) feels that the stewarti form, which $\mathbf{s e e}$, is only the juvenile form of the species.

The Howell 9585, distributed as typical L. rosmarinifolia, appears better regarded as $\boldsymbol{f}$. stewarti (Moldenke) Moldenke.

Additional citations: GALAPAGOS ISLANDS: Albemarle: J. T. Howell 9448 (Gg-262952, Gg-462954, Gg-462966); Wiggins \& Porter 255 (Z). James: Wiggins \& Duncan 278 (W-2813285). Narborough: F. R. Fosberg $450 \overline{14}(\mathrm{Ac})$.

LIPPIA ROSKARINIFOLIA Var. IATIFOLIA Moldenke

Additional bibliography: Hocking, Excerpt. Bot. A.12: 424 . 1967; Moldenke, Phytologia 14: 415. 1967; Moldenke, Résumé Suppl. 15: 4. 1967; Moldenke, Biol. Abstr. 49: 1325. 1968; Moldenke, Fifth Summ. 1: 138 (1971) and 2: 894. 1971; Moldenke in Wiggins \& Porter, F1. Galáp. Isls. 493 \& 494. 1971; Wiggins \& Porter, F1. Galáp. Isls. 989. 1971; Vandar Werff, Bot. Notiser 130: 96. 1977.

Wiggins \& Porter describe this plant as a slender tree, $8 \mathrm{~m}$. tall, with a trunk diameter to $10 \mathrm{~cm}$. at $1 \mathrm{~m}$. above the ground, growing on ridges at $470 \mathrm{~m}$. altitude, flowering and fruiting in February. Vander Werff (1977) says "L. rosmarinifolia var. latifolia, described from Santiago, also has entire or obscurely toothed leaves when mature and lobed leaves when fuvenilen.

Additional citations: GALAPAGOS ISLANDS: James: Wiggins \& Porter $278(\mathrm{Z})$. 
IIPPIA ROSMARINIFOIIA f. STEIARTI (Moldenke) Moldenke, stat. nov.

Synonyul: Lippia rosmarinifolia var. stewarti Moldenke, Phyto$\log 1$ a 2: 415-416. 1948. Lippia rosmarinifolia var. stewartii Moldenke in Wiggins \& Porter, FI. Galkp. Isls. 492 \& 494.1977.

Additional bibliography: Moldenke, Phytologia 14: 415. 1967; Moldenke, Fifth Summ. 1: 138 (1971) and 2: 564 \& 894. 1971; Moldenke in Wiggins \& Porter, Fl. Galáp. Isls. 492 \& 494. 1971; Wiggins \& Porter, Fl. Galáp. Isls. 989. 1971; Van den Werff, Bot. Notiser 130: 96. 1977.

Howell reports that the stems in this plant may layer (as they do on the typical form), the tips rooting when they touch the ground, creating a shrubby tangle difficult to traverse. He maintains that only the juvenile leaves are lobed, and found the plant growing at 2500 feet altitude. Actually, the type specimen, with distinctly pinnately lobed leaves, is in full anthesis, certainly not "juvenile" in the usual sense of that word. Van den Werff (1977) also feels that this form is not taxonomically valid. He says Moldenke......gives as diagnostic characteristics for var. rosmarinifolia: leaves entire or obscurely toothed. Var. stewartii is described as having pinnately lobed leaves. Howell, on the label of his collection......states that the juvenile leaves are lobed. My own field observations confirm this: van der Werff 2337 is a juvenile, non-flowering plant from the coast below Volcán Alcedo, and has distinctly lobed leaves. All flowering Lippia plants in the area had entire leaves. Apparently L. rosmarinifolia keeps the lobed leaves longer on the top of the volcanoes than in the coastal areas, but such plants with juvenile, lobed leaves do not deserve taxonomic recognition."

Additional citations: GAIAPAGOS ISIANDS: Albemarle: J. T. Howell 9585 (Gg- 462946, Gg-462947).

\section{IIPPIA ROTUNDTOIA Cham.}

Additional bibliography: Buek, Gen. Spec. Syn. Candoll. 3: 266. 1858; T. Peckolt, Bericht. Deutsch. Pharm. Gesell. 14: 471. 1904; Moldenke, Phytologia 12: 443-445. 1965; Moldenke, Fifth Summ. 1: 157 (1971) and 2: 543, 564, 568, \& 894. 1971; Troncoso, Darwiniana 18: 339 \& 410. 1974; Moldenke, Phytologia 31: 385 (1975) and 39: 162. 1978.

Recent collectors describe this plant as a shrub or small subshrub, $0.5-2 \mathrm{~m}$. tall, erect, or as an "herb with rather lignified shoots to $1.5 \mathrm{~m} . "$ long, the leaves apically acute or subacute, and have found it growing in red sandy loam or vermillion soil, in rocky campo, cerrado, cerrado with many shrubs, tall savanna woodland, "cerrado woodland on deep red latogol", and in moist parts of campo near roadways, at 1050-1100 m. altitude, flowering in May, June, and August to October, and fruiting in June, September, and October. The corollas are said to have been "lilac" on Hatschbach 36987 and Taxonomy Class Univ. Bras. 92, "pale-lilac" on Murça P1res 57939, "rose" on Hatschbach 27021 \& 29926, and "mauve-parple with yellow throat" on Ratter \& al. 2600 . 
Peckolt (1904) reports that $L$. rotundifolia is used as an aromatic in parts of Brazil.

Material of this species has been misidentified and distributed in some herbaria as L. lacunosa Mart. \& Schau. or as Fyptis sp. On the other hand, the W. R. Anderson 9747, Hunt \& Ramos 6256, A. Lutz 1095, Martius s.n. [in campis editis deserti, Jul. 1818], Murça Pires, Silva, \& Souza 9409, and Pohl s.n. [in Brasilia], distributed as L. rotundifolla, are all I. lacunosa Mart. \& Schau., while Carmo \& Macedo s.n. [Macedo 54li] is Hyptis sp. in the Lamiaceae.

Additional citations: BRAZIL: Distrito Federal: Hatschbach 36987 (Ld); Lindeman \& Haas 6031 (Ld); Ratter, Fonsêca, \& Castro R.2600 (N); Taxonomy Class Univ. Bras. 92 (W-2757739) . Minas Gerais: Duarte 8079 [Herb. Jard. Bot.Rio Jan. 122466] (N); Hatschbach 2702I (Ld, N, W-274464l), 29926 (Ld, N); Nacedo 3773 (E--1647189); Martius 1036 (Ku-126, Mu-127), s.n. [in campis ad fl. Arassuahy et prope Munbucas in desertis] (1ku-125); Murça Pires $57939(\mathrm{~N}, \mathrm{~W}-2571$ IOLA). MOUNTED ILLUSTRATIONS: Schau. in Mart., FI. Bras. 9: pl. 39 (sin.). 1851 (N, Z).

IIPPIA RUBIGINOSA Schau.

Additional bibliography: Buek, Gen. Spec. Syn. Candoll. 3: 266. 1858; Moldenke, Phytologia 14: 4í5. 1967; Angely, F1. Anal. \& Fitogeogr. Est. S. Paulo, ed. 1, 4: 835 \& di. 1971; Moldenke, Fifth Summ. 1: 157 (1971) and 2: 564, 565, \& 894. 1971; Moldenke, Phytologia 25: 229. 1973; Troncoso, Darwiniana 18: 337. 1974 .

Troncoso (1974) cites this species as the lectotype of the Section Goniostachyum Schau., a section which she fully describes there and circumscribes geographically. The Angely (1971) reference in the bibliography above is often cited by the incorrect title-page date "1970".

Recent collectors descrlbe L. rubiginosa as a shrub, $1 \mathrm{~m} . \mathrm{tal}$, and have encountered it on the "outer edge of river terraces along shore, top edge of terrace before few-meter descent to rivern, at $150 \mathrm{~m}$. altitude, flowering in February. They report the vernacular name, "alecrim". The corollas are said to have been "white" on Eiten \& Eiten 10730.

Additional citations: BRAzIL: Naranhfo: Eiten \& 쯔ten 10730 (N, W-2700166).

IIPPIA RUGOSA A. Chev.

Additional \& emended bibliography: Meikle in Hutch. \& Dalz., FI. W. Trop. Afr., ed. 2, 2: 432, 436, \& 437. 1963; Hepper, BuIl. Inst. Fond. Afr. Noire 27: 419 \& 495. 1965; Moldenke, Phytologia 14: 412 \& 415-416. 1967; Moldenke, Résumé Suppl. 15: 7. 1967; Moldenke, Fifth Summ. 1: 217, 222, \& 224 (1971) and 2: 894. 1971; Moldonke, Phytologia 39: 31 \& 181. 1978.

Hepper (1965) tells us that this plant is "common in disturbed areas" on the savannas of Northern Nigeria, where the stems are 
used as faggots, for building purposes, and in the mamfacture of beds. He gives its distribution as "in uplands of Guinea, N. Nigeria, E. \& W. Nigeria, and W. Cameroon".

Meikle (1963) reduces to synonymy here the "L. adoensis of $F$. W.T.A., ed. 1, 2: 270, partly, not of Hochst." and I. nigeriensis Moldenke. He cites the following specimens from the Kew herbarium: GUINEA: Chevalier 20410. NORTHERN NIGERIA: Coombe 9, Hepper 1892, Latilo FHI.37974, Lely 582, MacGregor 429, Meikle 824, Monod 9361 \& 9872. SOUTHERN NIGERIA: Hambler 585. CAMEROONS: Hepper 1269, Keay FHI.28522, Latilo \& Daramola FHI.28795, Maitland 1697. It has been collected in anthesis from September to January and in fruit in December and Jamary.

LIPPIA RZMDOWSKII Moldenke

Additional bibliography: Moldenke, Biol. Abstr. 47: 6794. 1966; Moldenke, Phytologia 13: 367. 1966; Hocking, Excerpt. Bot. A.11: 103. 1967; Heslop-Harrison, Ind. Kew. Suppl. 15: 80. 1974.

\section{IIPPIA SALAMENSIS Loes.}

Additional bibliography: Moldenke, Phytologia 12: $448--449$. 1965; Gibson, Fieldiana Bot. 24 (9): 207 \& 213. 1970; Moldenke, Fifth Summ. I: 80 (1971) and 2: 894. 1971.

Gibson (1970) foels that $L$. jurgenseni Briq. may be conspecific with I. salamensis, but I regard it as a synonym of L. pringlei Briq.

\section{IIPPIA SAIICIFOLIA Anderss.}

Additional bibliography: Moldenke, Phytologia 14: 415 \& 416. 1967; Moldenke, Fifth Summ. 1: 138, 183, \& 186 (1971) and 2: 894. 1971; Moldenke in Wiggins \& Porter, Fl. Galáp. Isls. 492-494. 1971; Wiggins \& Porter, Fl. Galáp. Isls. 989. 1971; Balgooy, Pacif. PI. Areas 3: 244. 1975.

\section{LIPPIA SATSA Griseb.}

Additional bibliography: V. J. Chapm., Salt Marshes \& Salt Deserts, ed. 1, 265 \& 381. 1960; Ruiz Leal, Revist. Facult. Cienc. Agrar. Mendoza 11: 170, 172, \& 173, fig. 7. 1964; Moldenke, Phytologia 12: 450-452. 1965; Rulz Leal, Biol. Abstr. 49: 3256. 1968; Moldenke, Fifth Summ. 1: 199 (1971) and 2: 894. 1971; V. J. Chapm., Salt Marshes \& Salt Deserts, ed. 2, 265 \& 381. 1974; Troncoso, Darwiniana 18: 334, 338, \& 410. 1974 .

Additional illustrations: Rulz Leal, Revist. Facult. Cienc. Agrar. Mendoza 11: 172, fig. 7. 1964.

Recent collectors describe this plant as a subshrub, $30 \mathrm{~cm}$. tall, with spreading branches, and have encountered it at $240 \mathrm{~m}$. altitude, flowering in January.

Troncoso (1974) cites Covas 1854l in the San Isidro herbarium and gives the distribution of the species in Argentina as C6rdoba, Santiago del Estero, Tucumán, La Rioja, and Mendoza. The corollas are said to have been "white" on Cabrera \& al. 16651 and on Krapo- 
vickas \& Crist6bal 17766.

Additional citations: ARGENTINA: C6rdoba: Cabrera, Solbrig, Torres, \& Vuillemier 16651 (S); Ellenberg 4410 (Ld). Mendoza: Krapovickas \& Crist6bal $\underline{11}_{569}$ (2); Rufz Leal 9099 (Tu162096); Semper s.n. [5/II/1944] (N). Santiago del Estero:

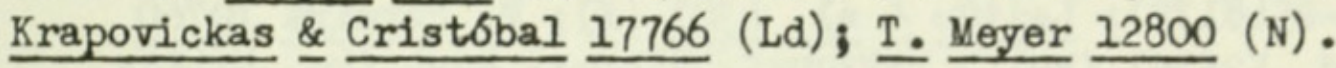

LIPPIA SALVIAEFOLIA Cham.

Additional \& emended bibliography: Buek, Gen. Spec. Syn. Candoll. 3: 266. 1858; Briq. in Chod. \& Hassl., Bull. Herb. Boiss., ser. 2, 4: [1155]--1156. 1904; Briq. in Chod. \& Hassl., P1. Hassler. 2: [481]-492. 1904; R. C. Foster, Contrib. Gray Herb. 184: 170. 1958; Moldenke, Phytologia 14: 476. 1967; Moldenke, Résumé Suppl. 15: 21. 1967; Angely, FI. Anal. \& Fitogeogr. Est. S. Paulo, ed. 1, 4: 835, 836, \& dd. 1971; Moldenke, Fifth Summ. 1: 157 \& 199 (1971) and 2: 549, 563, 565, 566, \& 894. 1971; Moldenke, Phytologia 24: 136. 1972; Troncoso, Darwiniana 18: 335, 337, \& 410. 1974; Moldenke, Phytologia 39: 82. 1978.

Recent collectors refer to this plant as a shrub, $0.8-3 \mathrm{~m}$. tall, or branched and subprostrate, the stem to $2 \mathrm{~cm}$. in diameter $1 \mathrm{~m}$. above the ground, and the flowers fragrant. They have found it growing in rocky soil, cerrado, and among cutover cerrado vegetation, as well as on roadside banks in cerrado areas, at 500-1200 m. altitude, flowering from February to April and in November and December. Anderson and his associates encountered it "in forest in areas of sloping rocky cerrado bordered by for est along streams and by grassy recently burned campo, in sandy soil and sandstone".

The corollas are said to have been "white" on Anderson \& al. 36169, Eiten \& al. 6026, Fiebrig 4234, Hassler 6720, Pereira 10760, Schulz 7107, and Schwarz 3456, "white, the tube yellow within" on Irwin \& al. 28042, and "cream-white" on Leitao \& al. 4301.

The Angely (1971) reference cited in the bibliography above is sometimes cited as published in 1970, the erroneous titlepage date. This author recognizes both $\mathrm{L}$. polycephala Briq. and I. salviaefolia Cham. as distinct species; for the former he gives the distribution as Paraguay, Piaul, Minas Gerais, and Sæo Paulo and for the lattor Mato Grosso, Minas Gerais, and Sao Paulo. I regard the two taxa as conspecific. Troncoso (1974) cites Martínez Crovetto 9754 from Misiones in the San Isidro herbarium and gives the geographic distribution of the species as "Brasil austral, Paraguay, Bolivia y NE Argentina: Misiones".

Material of L. salviaefolia has been misidentified and distributed in some herbaria as Lantana sp. and as "Lippia mollis Mart. var." On the other hand, the Martius s.n. [in pascuis ad V. N. da Rainha, Mart.], distributed as L. salviaefolia, is the type collection of L. grata Schau. 
Additional citations: BRAZIL: Mato Grosso: Martius 1032 (Mu-127, Mu-1218, Z). Minas Gerais: Anderson, Stieber, \& Kirkbride 36169 (Ld, N, W-2709300); Irwin, Fonsêca, Souza, Reis dos Santos, \& Ramos 28042 (Ld). S\$o Paulo: Eiten, Eiten, \& Mimura 6026 (N, W-2687156); I. S. Gottsberger 47 [8] (Ld), 136 [8] (Ld); Labour-

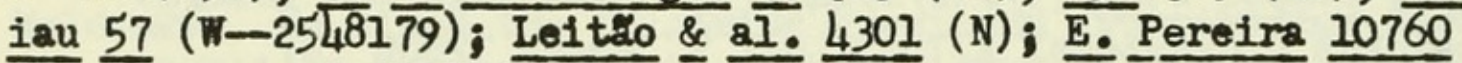
[Herb. Brad. 52686] (Mp). PARAGUAY: Fiebrig 4234 (Mu-4, 418); Hassler 6720 (Ca-944346); Schinini 4349 (Id). ARGENINA: Misiones: A. G. Schulz 7107 (N); G. J. Schwarz 3456 (N), 5733 (N).

LIPPIA SANDWITHIANA Moldenke

Additional bibliography: Moldenke, Phytologia 12: 456-457. 1965; Moldenke, Fifth Suwm. 1: 186 (1971) and 2: 894. 1971.

LIPPIA SATUREIAFFOIIA Mart. \& Schau.

Synonymy: Lippia saturejaefolia Mart. \& Schau. ex Solered., Syst. Anat. Dicot. Frganz. 255. 1908. Lippia saturaerefolia Mart. ex Moldenke, Phytologia 36: 4h, in syn. 1977.

Additional bibliography: Buek, Gen. Spec. Syn. Candoll. 3: 266. 1858 ; T. Peckolt, Bericht. Deutsch. Pharm. Gesell. 14: 470. 1904; Solered., Syst. Anat. Dicot. Ergänz. 255. 1908; J. F. Macbr., Field Mus. Publ. Bot. 13 (5): 649. 1960; Moldenke, Phytologia 12: 457-458. 1965; Moldenke, Fifth Summ. 1: 157 (1971) and 2:894. 1971; Moldenke, Phytologia 23: 433. 1972.

Peckolt (1904) records the vernacular name, "alecrim do mato" (which he translates as "wilder Rosmarin"), for this species.

Additional citations: BRAZIL: Minas Gerais: Martius 1377 [Macbride photos 20333] (Mu-128-type, Z--isotype).

\section{IIPPIA SAVORYI Meikle}

Additional \& emended bibliography: Meikle in Hutch. \& Dalz., F1. W. Trop. Afr., ed. 2, 2: 432, 436, \& 437. 1963; Townsend, Excerpt. Bot. A.7: 364. 1964; Moldenke, Phytologia 14: 417. 1967; Moldenke, R6sumé Suppl. 15: 6. 1967; G. Taylor, Ind. Kew. Suppl. 14: 79. 1970; Moldenke, Fifth Summ. 1: 220, 222, 231, \& 244 (1971) and 2: 549, 560, 568, \& 894. 1971; Hegnauer, Chemotax. PfI. 6 [Chem. Reihe 21]: 661. 1973; Moldenke, Phytologia 38: 263 \& 266 (1978) and 39: 31, 32, 80, 91, 92, \& 181. 1978.

Recent collectors describe this plant as a small, erect, palegreen perennial or anmual herb, 12-16 inches tall, strongly aromatic (but not of lemons) and have encountered it on flats of red loamy sand and on dry Acacia savannas, at 2800 feet altitude, flowering in February, March, October, and November, fruiting in March, October, and November. The corollas are said to have been "white" on Merzmenler \& Giese 666 and "creamy-white" on Noel 2403. Leistner refers to it as "occasional" in the Transvaal. Kinges notes of his no. 1869 that the leaves are narrower than in no. 1868 and that "the herbs have an overall different appearance". Meikle (1963) notes that the species is related to L. chevalieril Moldenke.

[to be continued] 


\section{$2 \mathrm{BHL}$ Biodiversity Heritage Library}

Moldenke, Harold N. 1978. "Additional notes on the genus Lippia. XI." Phytologia 39, 434-456. https://doi.org/10.5962/bhl.part.7623.

View This Item Online: https://www.biodiversitylibrary.org/item/47392

DOI: https://doi.org/10.5962/bhl.part.7623

Permalink: $\underline{\text { https://www.biodiversitylibrary.org/partpdf/7623 }}$

\section{Holding Institution}

New York Botanical Garden, LuEsther T. Mertz Library

\section{Sponsored by}

The LuEsther T Mertz Library, the New York Botanical Garden

\section{Copyright \& Reuse}

Copyright Status: In copyright. Digitized with the permission of the rights holder.

Rights Holder: Phytologia

License: http://creativecommons.org/licenses/by-nc-sa/3.0/

Rights: https://biodiversitylibrary.org/permissions

This document was created from content at the Biodiversity Heritage Library, the world's largest open access digital library for biodiversity literature and archives. Visit BHL at https://www.biodiversitylibrary.org. 